\title{
Prevalence of cystic echinococcosis in pigs from Slovakia, with evaluation of size, fertility and number of hydatid cysts
}

\author{
L. TURČEKOVÁ ${ }^{1}$, V. ŠNÁBEL ${ }^{1}$, V. DUDIŇÁK ${ }^{1}$, V. GAŠPAR ${ }^{2}$, P. DUBINSKÝ $^{1}$ \\ ${ }^{1}$ Parasitological Institute, Slovak Academy of Sciences, Košice, Slovakia, E-mail: turcela@saske.sk; \\ ${ }^{2}$ Regional Veterinary and Food Administration, Prešov, Slovakia
}

\begin{abstract}
Summary
The regional occurrence of cystic echinococcosis in slaughtered pig from Slovakia was studied in the period of 2000 - 2008, along with the quantitative parameters associated with the establishment of cysts (intensity of infection, fertility, size). From 103 pig livers collected from abattoirs in 35 sites Slovakia as suspected for Echinococcus infection, 63 were positive for cystic echinococcosis, whereas in 40 livers cysticercosis was diagnosed. Fertile cysts with echinococcal protoscoleces were recorded in $25.4 \%$ of positive pigs, with the $8.9 \%$ fertility rate and the intensity of infection reaching value of 5.9 cysts per liver. The average size of fertile cysts was more than three times larger than diameter of sterile cysts (diameters of $4.67 \mathrm{~cm}$ vs. $1.37 \mathrm{~cm}$, respectively). No significant differences in relative amounts of fertile and sterile cysts were found among counties $(\mathrm{P}=0.15)$. The annual prevalence of $E$. granulosus in pigs in $2000-2008$ has ranged from $0.02 \%$ to $0.13 \%$ (average rate $0.08 \%$ ), with the decreasing tendency over the period, especially after 2005. The most heavily affected areas with cystic echinococcosis over $2006-2008$ were indicated in Prešov (eastern Slovakia, $0.68 \%$ prevalence) and Komárno districts (southwestern Slovakia, $0.26 \%$ prevalence). Obtained data are relevant in designing regional control strategies to suppress the occurrence of disease in livestock and risk for humans to be infected.
\end{abstract}

Keywords: Echinococcus; hydatid cysts; prevalence; fertility; intensity of infection; cyst size

\section{Introduction}

Cystic echinococosis (CE) caused by larval stage of Echinococcus granulosus tapeworm is a chronic zoonotic infection, mainly transmitted in a cycle between dog as definitive host and livestock as intermediate hosts. Humans are occasional intermediate hosts, and $\mathrm{CE}$ accounts for more than $95 \%$ of the estimated $2-3$ million human global cases affected by Echinococcus parasites (Budke, 2006). The infection in intermediate hosts results in the formation of a hydatid cyst (metacestode larvae). A mature fertile cyst is frequently unilocular and is manifested as anechoic, fluid-filled lesion. More than $90 \%$ cysts occur in liver, lungs or both (McManus et al., 2003). The cyst wall consists of an inner nucleated germinal layer, which gives rise to brood capsules and protoscoleces, and an outer acellular laminated layer adjacent to the host tissue. All cysts start to develop as a typical small unilocular cyst with cyst fluid. In some cases, development progresses no further and the cyst is said to be sterile (nonfertile). In most other cases, however, protoscoleces subsequently bud within brood capsules attached to the germinal layer and are released into cyst fluid. This internal structure can be remained, but collapsed cyst walls, calcification and the presence of additional daughter cysts are often seen. Such heterogeneity in cyst structure has been an issue for clinicians how to treat human $\mathrm{CE}$ and is important for monitoring progression of the disease (Altintas et al., 2007; Ćulafić et al., 2007). If the viable portions of germinal layer, brood capsule wall or protoscoleces are present, the cyst has the ability to regenerate in some form (Kamenetzky et al., 2000). Some discussions have evolved about the origin of daughter cysts. The former major assumption that these arise by budding from the germinal layer has no histological support and view that cysts develop directly from protoscoleces currently prevails (Rogan et al., 2006). In comparison with investigations in humans, little research has been directed toward the development of $E$. granulosus infection in domesticated animals such as pig. The pig-dog cycle is the most important cycle for perpetuating this parasite in central Europe (Romig et al., 2006). No studies have yet determined the regional-specific prevalence or intensity of infection, nor examined cyst size and fertilities in pig from Slovakia. The pilot study was 
therefore undertaken to examine regional occurrence of the tapeworm over the last decade and to assess quantitative parameters associated with the establishment of cysts in pig intermediate host and areas mostly affected by disease.

\section{Materials and methods}

In a period of $2000-2008$, livers with lesions from 103 slaughtered pigs were collected from 35 sites in 7 counties of Slovakia (sites with findings of fertile/sterile echinococcal cysts are shown in Fig. 1). Frozen livers were transported from abattoirs to the laboratory. Cystic formations were diagnosed as being originated due to echinococcosis or cysticercosis. Material was kept at $-20^{\circ} \mathrm{C}$ until microscopical and morphological examinations at the laboratory. Before processing, frozen cysts were rinsed in $70 \%$ ethanol and cut by sterile scissors. Frozen cysts were excised and transferred into beakers, in which the size of cysts was measured at the laboratory temperature. The whole cyst content was passed through a $100 \mu \mathrm{m}$ sieve to remove wall layers and debris. Resulting hydatid fluid was then centrifuged at $6000 \mathrm{rpm}$ for $10 \mathrm{~min}$. The sediment was washed in phosphate buffer saline $(\mathrm{pH} 7.2)$, and re-centrifuged under same conditions. Supernatant was carefully removed and final sediment and germinal layers were observed under light microscope to determine the cyst fertility. Fertile cyst was considered the cyst with the presence of protoscoleces in the hydatid fluid and/or attached to the germinal layer. In sterile cysts degenerative modifications (cysts with purulent inflammation, caseous necrosis or calcified cysts) were often seen. Morphometric data of echinococcal cysts were evaluated by statistical methods with respect to their geographical origin, number and fertility.

Cyst size related to the geographical origin was evaluated by ANOVA (analyses of variance), supplemented by post hoc analysis by Duncan's test was performed when needed. Relation between fertility and geographical origin was determined by use of Kruskall-Wallis ANOVA with the subsequent HSD (unequal N) test. For evaluation of

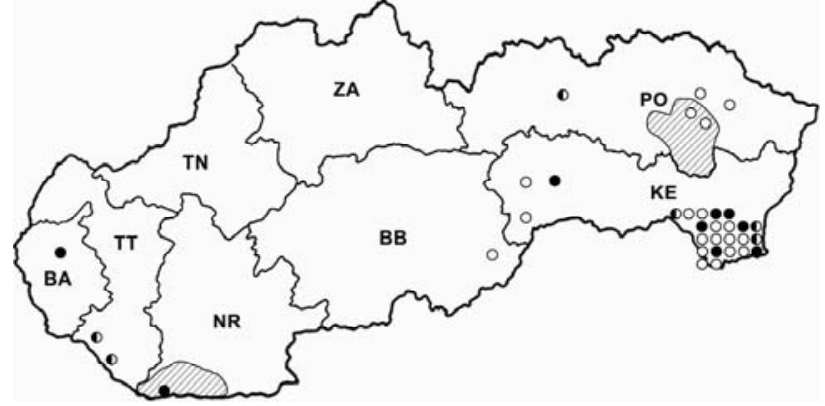

Fig. 1. Illustration of sites with findings of cystic echinococcosis (CE) in slaughtered pigs in Slovakia partitioned into counties. CE-positive counties: BA - Bratislava county, TT - Trnava county, NR - Nitra county, BB - Banská Bystrica county, PO - Prešov county, KE Košice county. Districts mostly affected by CE in $2006-2$ 008, Prešov in Prešov county (prevalence of $0.68 \%$ ), Komárno in Nitra county (prevalence of $0.26 \%$ ), are designated by hatched areas with diagonal lines. - site with recorded fertile cysts; $\bigcirc$ - site with recorded sterile cysts; - site with both fertile and sterile cyst relation between cyst size and fertility Student's t-test was used. Spearman's rank correlation coefficient was used for regression analysis of size cysts and their number in the liver. Values for cyst sizes were logarithmically transformed to fit this analysis. All statistical analyses were performed by Statistica 6.1 software (StatSoft, CR, Prague) program. Significant differences were considered when $\mathrm{P}<$ 0.05 .

\section{Results}

From 103 pig livers obtained from abbatoirs as suspected for CE infection, 63 (i.e. $61.2 \%$ ) were positive for cystic echinococcosis (findings are demonstrated in Fig. 2). In remaining 40 (38.8\%) livers cysticercosis was diagnosed (findings illustrated in Fig. 3). Overall, 463 cysts were recorded, 372 of which were due to echinococcus and 91 due to cysticercus. Numbers of examined livers and cysts according to Slovak counties are summarized in Table 1. Only echinococcal cysts were subjected to statistical evaluations. Mixed infections of echinococci and cysticerci were recorded in $4(3.9 \%)$ of livers.
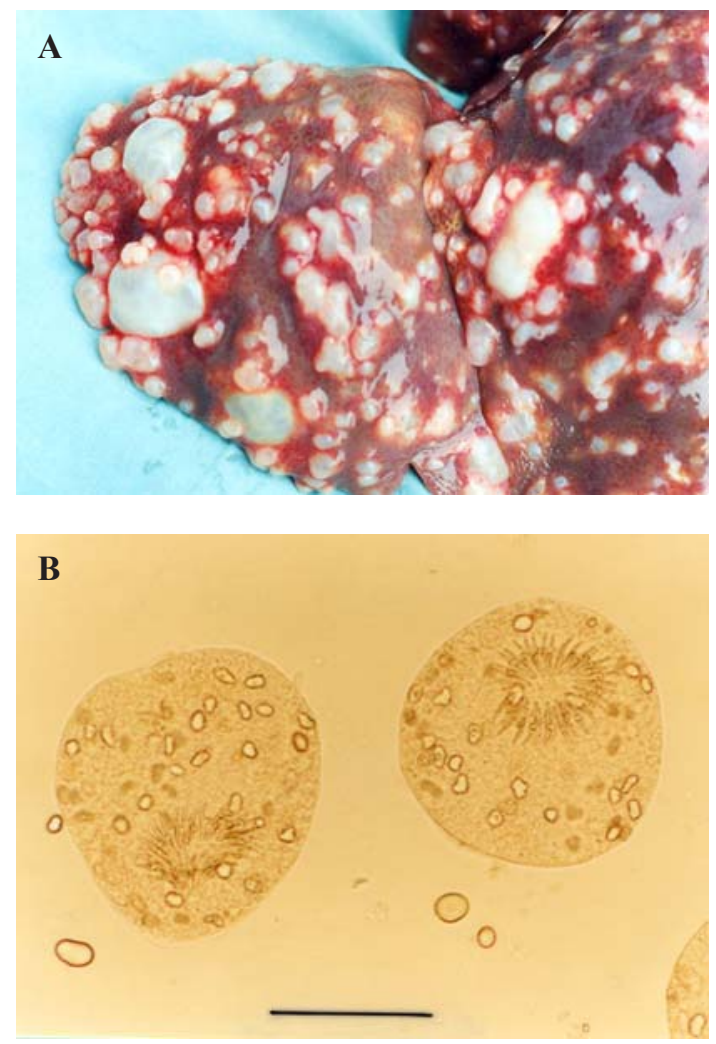

Fig 2. A - Echinococcus granulosus cysts in pig liver; B - isolated protoscoleces from cysts. Scale bar - $100 \mu \mathrm{m}$.

\section{Regional intensities of infection}

In 63 pigs infected with $\mathrm{CE}$, the intensity of infection (number of hydatid cysts per positive animal) has ranged from 1 to 36 cysts per liver, with the average intensity 5.9 (Tab. 2). Significant overall differences $(\mathrm{F}=4.09, \mathrm{P}<$ $0.01)$ at this parameter were detected between examined 
Table 1. Liver examination of slaughtered pigs according to Slovak counties for tapeworm presence

\begin{tabular}{lccccc}
\hline \multirow{2}{*}{ County } & $\begin{array}{c}\text { Number of } \\
\text { livers }\end{array}$ & $\begin{array}{c}\text { Livers with } \\
\text { echinococcus }\end{array}$ & $\begin{array}{c}\text { Livers with } \\
\text { cysticercus }\end{array}$ & \multicolumn{2}{c}{ Number of cysts with } \\
\cline { 5 - 6 } BA & 1 & 1 & 0 & echinococcus & cysticercus \\
TT & 2 & 2 & 0 & 42 & - \\
NR & 2 & 2 & 0 & 17 & - \\
TN & - & - & - & - & 2 \\
ZA & 1 & 1 & 1 & 24 & 2 \\
BB & 2 & 7 & 5 & 38 & 15 \\
PO & 12 & 50 & 33 & 249 & 72 \\
KE & 83 & 63 & 40 & 372 & 91 \\
\hline Total & 103 & BA - Bratislava; TT - Trnava; NR - Nitra; ZA - Žilina; BB - Banská Bystrica; PO - Prešov; KE - Košice
\end{tabular}

counties. At the same time, no significant difference was found when counties within groups established by Bratislava, Prešov, Košice, Nitra counties and Trnava, Banská Bystrica counties were compared, whereas these groups differed significantly $(\mathrm{P}<0.05)$. Massive infections (more than 10 cysts in liver) were diagnosed in $17.5 \%$ of pigs $(11 / 63)$.
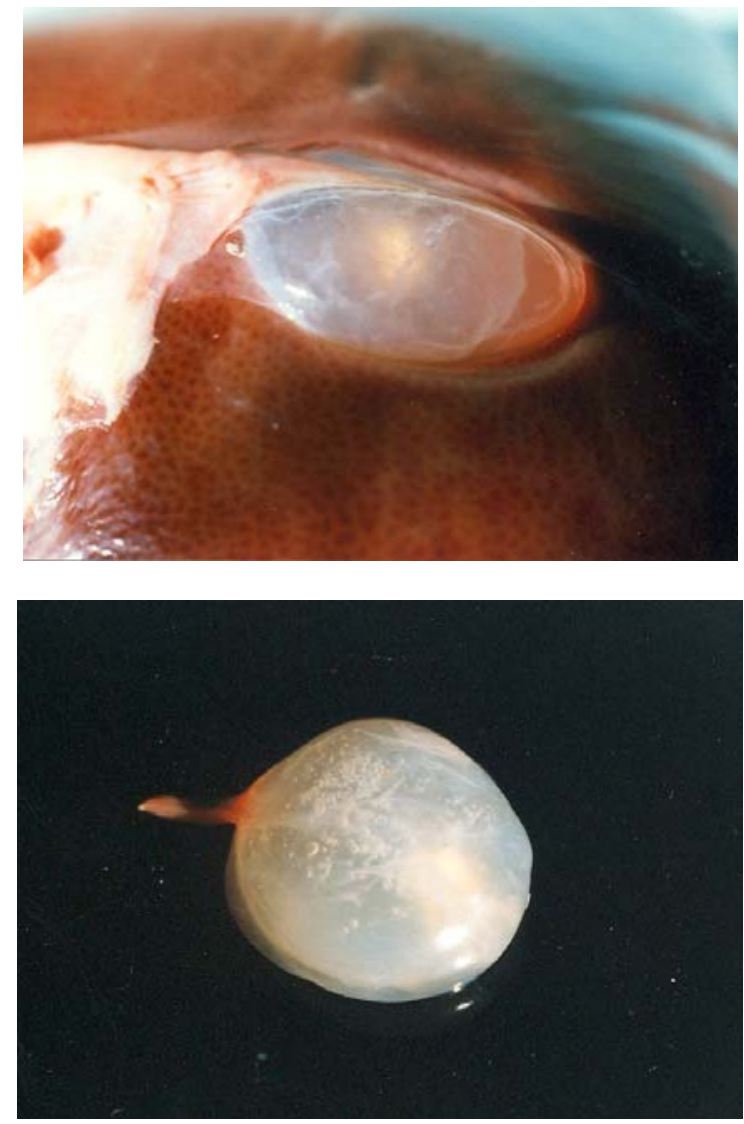

Fig. 3. A - Cysticercus cysts in pig liver; B - cysticercus excised from pig liver

Mean size of cysts

When comparing average diameters of cysts, more striking differences between counties were recorded (Tab. 2, Fig. 4). Lesion sizes from Bratislava county were excluded from this statistical evaluation as only two cysts were obtained. Largest cysts were seen in livers from Banská Bystrica county, the size of which significatly differed from cysts in Prešov county at confidence level $\mathrm{P}<0.01$ and at level $\mathrm{P}<0.001$ when related to remaining counties. This could have been influenced by the fact that examined cysts from Banská Bystrica county originated from one liver. Smallest diameters of cysts were obtained from Trnava county, but their size was not significantly different from those obtained from Košice, Nitra and Prešov counties.

\section{Distribution of fertile and sterile cysts}

No significant differences in relative proportional amounts of fertile and sterile cysts were found among counties ( $\mathrm{P}=$ 0.15). From a total number of 372 cysts $33(8.9 \%)$ were fertile (Table 2). In Banská Bystrica and Prešov counties the values were lower $(0 \%$ and $5.3 \%$, respectively), but this difference was not yet statistically significant $(\mathrm{P}>$ $0.05)$. The closest proportional value of the occurrence of fertile cysts to the overall value was recorded in Košice county $(8.7 \%)$. Slightly higher proportions were ascertained in Nitra $(11.8 \%)$ and Trnava $(16.7 \%)$ counties, without exceeding the probability limit for statistical significance. The proportion value in cysts from Bratislava county $(\mathrm{P}<0.001)$ was significantly different, but the cyst number (2) from this county was too small for being considered for statistical evaluation.

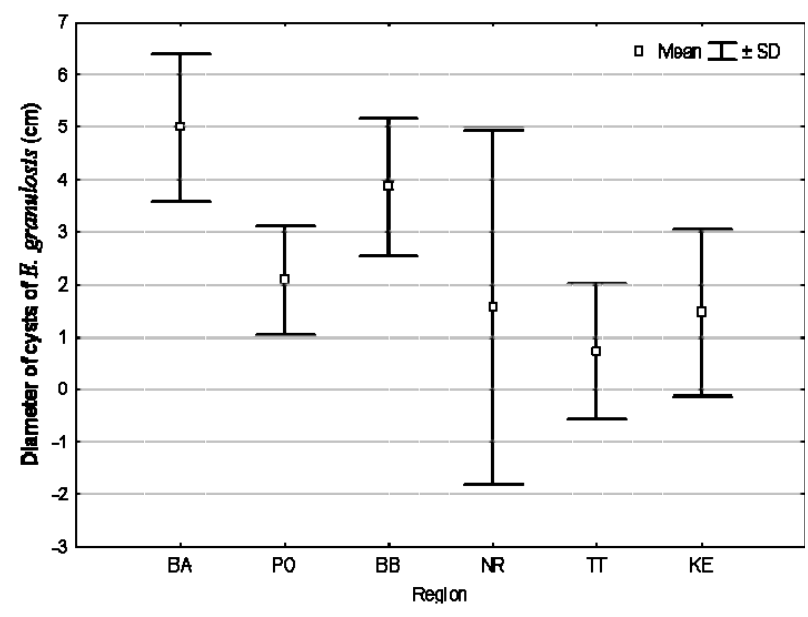

Fig. 4. Graph depicting distribution of cyst sizes according to counties Size of sterile and fertile cysts

Size of echinococcal cysts in relation to their fertility was evaluated. Highly significant difference in cyst diameters 
Table 2. Numbers, sizes and fertility of echinococcal cysts

\begin{tabular}{|c|c|c|c|c|c|}
\hline \multirow{2}{*}{ County } & Cyst numbers & Cyst sizes $(\mathrm{cm})$ & \multirow{2}{*}{$\begin{array}{l}\text { Number of } \\
\text { sterile cysts }\end{array}$} & \multirow{2}{*}{$\begin{array}{l}\text { Number of } \\
\text { fertile cysts }\end{array}$} & \multirow{2}{*}{$\begin{array}{c}\text { Proportion of } \\
\text { fertile cysts }(\%)\end{array}$} \\
\hline & \multicolumn{2}{|c|}{ Mean \pm S.D. } & & & \\
\hline $\mathrm{BA}$ & $2,0 \pm 0,0$ & $5,00 \pm 1,41$ & 0 & 2 & 100 \\
\hline $\mathrm{TT}$ & $21 \pm 15^{*}$ & $0,73 \pm 1,30$ & 35 & 7 & 16.7 \\
\hline NR & $8,5 \pm 9,2$ & $1,56 \pm 3,37$ & 15 & 2 & 11.8 \\
\hline $\mathrm{BB}$ & $24 \pm 0,0^{*}$ & $3,87 \pm 1,31$ & 24 & 0 & 0 \\
\hline PO & $5,4 \pm 7,0$ & $2,08 \pm 1,04$ & 36 & 2 & 5.3 \\
\hline $\mathrm{KE}$ & $5,0 \pm 5,6$ & $1,46 \pm 1,59$ & 229 & 20 & 8.7 \\
\hline Total & $5,9 \pm 7,2$ & $1,79 \pm 3,01$ & 339 & 33 & 8.9 \\
\hline
\end{tabular}

BA - Bratislava; TT - Trnava; NR - Nitra; ZA - Žilina; BB - Banská Bystrica; PO - Prešov; KE - Košice

*counties with significantly higher cyst numbers relative to remaining counties $(\mathrm{P}<0.05)$

was observed between fertile and sterile cysts $(t=-12,037$, df $=370 ; \mathrm{P}<0.001)$; the average diameter measured in fertile cysts was three times larger than average diameter in sterile cysts, with mean values $4.67 \mathrm{~cm}$ and $1.37 \mathrm{~cm}$, respectively (Fig. 5).

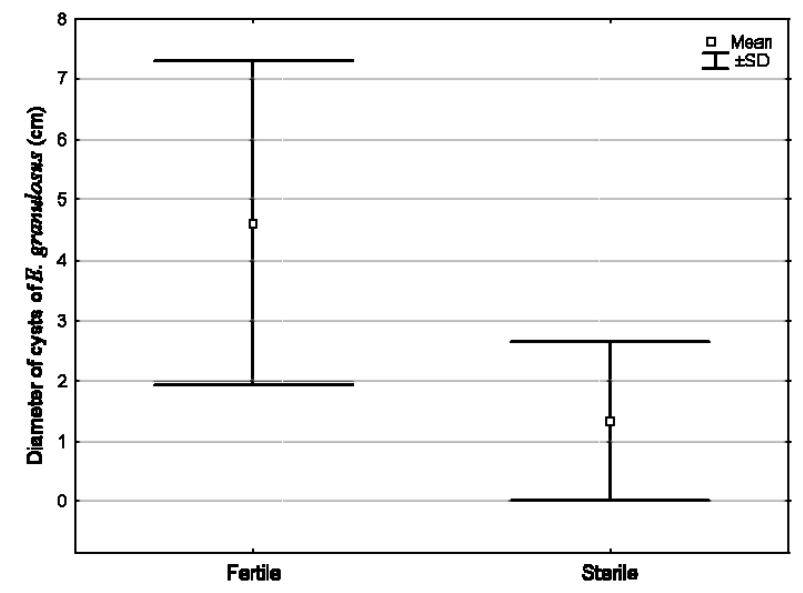

Fig. 5. Graph depicting cyst size in relation to fertility/sterility

Regression analysis of number and size of cysts

In evaluation of relation of number of cyst size (regardless of fertility/sterility) and their number in liver the tendency for decreased size with increased number of cysts in liver was apparent. With increasing number of cysts the trend for cyst diminution has declined. As shown in Fig. 6, when size was reciprocally transferred, positive linear relation of

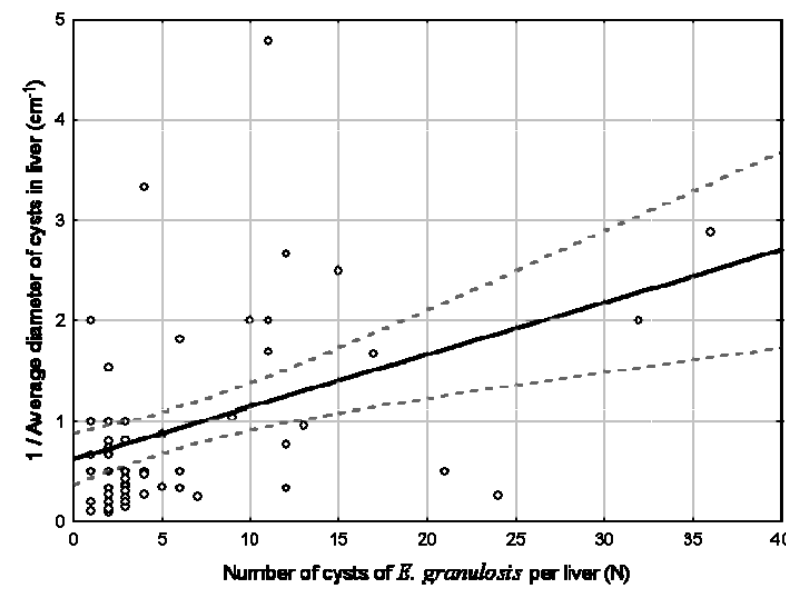

Fig. 6. Graph depicting relation between number and size of cysts 154 transformed data with respect to the increase in cyst number in liver was evident, resulting in highly significant correlation coefficient $(\mathrm{P}<0.001)$.

\section{Discussion}

In the present study, regional patterns derived from numbers, fertility and size of E. granulosus larvocysts in pig livers from Slovakia were studied. The proportion of animals with fertile cysts is an important indicator as only viable cysts assure the completion of life cycle and an active role in E. granulosus transmission. Fertile cysts were found in $25.4 \%(16 / 63)$ of CE positive pigs in our report. Overall fertility rate in examined cysts was $8.9 \%$ $(33 / 372)$, which is lower value compared to situation in Lithuania where pigs harboured $23.4 \%$ (11/47) of fertile cysts (Bružinskaite et al., 2009). This would be likely accounted for by higher proportion of young pigs $(<1$ year) included in the survey within available records from Slovakia (92.2\%); we do not presume differences in infectivity of G7 genotypes circulating in these countries. Older pigs are more effective parasite transmitters due to both the higher chance to be infected with parasite and the drop in immunity owing to aging which allows the cysts to develop protoscoleces. Varcasia et al. (2008) found high fertility rate in Peloponnesus (Greece), where $50 \%$ (14/28) of goats were infected with CE (G7 genotype), thus confirming suitability of this intermediate host for G7 transmission. Unlike this, for highly infective $E$. granulosus sensu stricto (G1 genotype) for humans, a high proportion of sterile cysts in pig is characteristic (Eckert et al., 1993). This general feature did not conform to findings of Varcasia et al. (2006) from Sardinia, where a remarkable $69.2 \%(18 / 26)$ fertility rate was recorded in pigs infected with G1 (highly predominant variant in the region). Pig host thereby potentially plays an important role in CE transmission in this island, in addition to sheep. The average cyst diameter of Echinococcus cysts, herein measured in 63 infected pig livers, was $1.79 \mathrm{~cm}$. The average diameter of fertile cysts was more than three times larger than diameter of sterile cysts $(4.67 \mathrm{~cm}$ vs. $1.37 \mathrm{~cm})$. The same pattern was also found in a study of Dueger and Gilman (2001) on ovine echinococcosis in Peru, in which for $1-\mathrm{cm}$ increase in size the odds of having protoscoleces increased by 5.5 -fold (mean diameter of fertile cysts was $5.48 \mathrm{~cm}$ ). Based on survey on 100 necropsied yaks Yang et 
al. (2009) derived that frequencies of fertile cysts increased in lesions with a diameter $>2.1 \mathrm{~cm}$. Pawlowski (1997) considered that cysts larger than $5 \mathrm{~cm}$ usually induce symptoms in humans. Many previous studies illustrated that large cysts, $10-20 \mathrm{~cm}$ in diameter, are generally fertile (Rausch, 1993). In our survey largest cysts were obtained from sites in Komárno district (Nitra county, southwestern Slovakia), with diameters of 10 and $11 \mathrm{~cm}$ (found in single liver), and in Trebišov district (Košice county, eastern Slovakia) $9.5 \mathrm{~cm}$ lesion was recorded, all hydatids were fertile.

The average intensity of infection in pigs was 5.9 cysts per liver in the present survey (G7 genotype involved, Šnábel et al., 2008). In recent studies measuring this parameter of parasite burden, a high intensity of infection was found especially in sheep in Peloponnesus (Greece), reaching a value of 16.3 (measured in 64 animals, $53.1 \%$ fertility; G1 involved), and cattle in Sardinia (Italy) - 12.5 (in 14 animals, although only $2.6 \%$ of animals harbored fertile cysts; G1 involved) (Varcasia et al., 2006, 2008). The eight cysts per yak and 5.8 cysts in sheep/goats were found in western Sichuan, China (Yang et al., 2009), 8.1 in cattle and 4.3 in buffalo in Campania, southern Italy (Capuano et al., 2006; Rinaldi et al., 2008), 7 in sheep in Sardinia (Varcasia et al., 2006), and 5.8 in goats in Greece (Varcasia et al., 2008).

The typical transmission pattern of the "pig strain" (G7 genotype) is maintained between pig and dog. In a region of central-eastern Europe, a contiguous area of G7 was established that encompasses at least territories of Poland, Slovakia and Ukraine (Kedra et al., 1999; Šnábel et al., 2000; Turčeková et al., 2003). The G7 was also reported from isolated foci of Spain (Daniel-Mwambete et al., 2004), Italy, Sardinia (Varcasia et al., 2006), Greece (Varcasia et al., 2008), Romania (Bart et al., 2006), Lithuania (Bružinskaitė et al., 2009), Turkey (Šnábel et al., 2009), Armenia (Gevorgyan et al., 2006), Argentina (Kamenetzky et al. 2002) and Mexico (Cruz-Reyes et al., 2007). Besides domestic pigs, wild boar was confirmed as transmitting pig strain in Ukraine, Spain and Germany (Kedra et al., 2000; Gonzales et al., 2002; Dinkel et al., 2006), and parasite was also found in European beaver in Poland (Tkach et al., 2002) and cattle in Slovakia (Turčeková et al., 2003). In Europe, human infections with G7 (and its variant G9) were confirmed in Poland (Scott et al., 1997) and Slovakia (Turčeková et al., 2003). There is circumstantial evidence suggested that humans are poorly susceptible or refractory to infections with pig strain due to little evidence of human $\mathrm{CE}$ in endemic foci of $\mathrm{G} 7$ (Pawlowski, 1985; Thompson et al., 2008). Infectivity of G7 for humans appears to be lower compared with closely related G6 genotype (camel strain), which e.g. in Argentina contributes for up to $37-44 \%$ of human CE cases, despite the presence of highly infective sheep strains (G1, G2 genotypes) in the country (Rosenzvit et al., 1999; Guarnera et al., 2004). The close relationships among camel (G6), pig (G7) and G8/G10 (cervid) strains were demonstrated by recent genetic studies (Lavikainen et al., 2006; Nakao et al., 2007; Moks et al., 2008). If the species categorization for this cluster is taxonomically verified, in terms of time priority it is named E. canadensis according to the former designation of cervid strain (Webster and Cameron, 1961). However, some genetic structuring between G6/7 and G8/G10 pairs is apparent from both mitochondrial and nuclear evidences (Nakao et al., 2007; Saarma et al., 2009), and it has to be yet resolved whether these groups of genotypic pairs merit an additional species/subspecies status.

Within herein examined echinococcal samples from Slovak pigs, genetic structuring of selected isolates was studied in fragments of mitochondrial genes (cox1, atp6, nad1) along with those from neighbouring countries (Ukraine, Poland, Hungary) (Šnábel et al., 2008). In cox1 fragment, the two G7 lines were detected, differing in two nucleotide sites. Major line was composed of 20 isolates from Slovakia, 5 isolates from Ukraine and 1 from Poland (assigned to as G7A variant). The G7B variant with two transitive mutations was detected in three samples from north-eastern Ukraine (Sumy region) and one isolate from southeastern Slovakia (Vel'ký Horeš, Trebišov district). In atp6 gene, three polymorphic sites were detected within samples from Slovakia. The most common polymorphic site (238) with G/T substitution was recorded in the above isolate from Trebišov district and two locations (Dunajská Streda and Komárno districts) in southwestern Slovakia. All examined samples from central-eastern European region were identified as bearing the G7 genotype structure, except for Hungarian isolate (Békés county) from patient attributed to the G1. Endemic foci of G1 in Ukraine and southern European countries cannot exclude the spread of this genotype to Slovakia in further period, through mobile definitive hosts as jackal and wolf and/or livestock market.

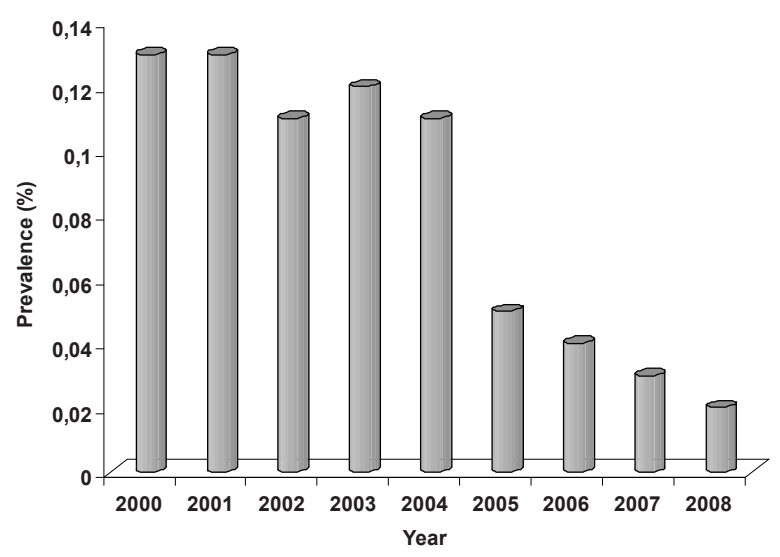

Fig. 7. Graph with annual prevalence rates of cystic echinoococcosis in slaughtered pigs in Slovakia over 2000-2008

Average annual prevalence of $\mathrm{CE}$ in slaughtered pigs in Slovakia in 2000 - 2008 was $0.08 \%$ (Štefančíková \& Dubinský, 2000 - 2008). As shown in Fig. 7 summarized according to reports from regional veterinary services, the prevalence of E. granulosus ranged from 0.02 to 0.13 , with the decreased tendency over the period, especially since 
2005. Compared with the situation in 1990's with the average rate of $0.18 \%$ (Svobodová et al., 2006), more than two-fold reduction of the disease occurrence in pig was recorded. Based on reports from surveillances of zoonoses in Slovakia (Štefančíková \& Dubinský, 2000 - 2008) we have derived that areas attributed to districts of Prešov (eastern Slovakia) and Komárno (southwestern Slovakia) have been the most important endemic areas of $\mathrm{CE}$ in pig over the last 3 years, with average prevalences of $0.68 \%$ and $0.26 \%$, respectively. Respective areas are designated by hatched lines in Fig. 1. Within neighbouring countries, in Hungary the prevalence of $\mathrm{CE}$ in pigs decreased from $0.20 \%$ in 1994 to $0.11 \%$ in 2004 (Svobodová et al., 2006), i.e. to a similar amount as observed in Slovakia in the corresponding period. Czech Republic has documented only 16 pigs with CE in 2004 and no other livestock was infected (Šmatlová \& Papežíková, 2005). Higher overall prevalence of CE in pig is being registered in Poland (4.32 $\%$ in 2002) compared with Slovakia, with eastern voivodships of the country more encountered by disease (Svobodová et al., 2006).

Annually, $0-7$ human clinical cases were confirmed in Slovakia through 2000 - 2008 (except for 2000 with 31 registered cases), accounting for the average incidence rate (per 100000 population) of 0.103 (Kinčeková et al., 2008). The incidence of $\mathrm{CE}$ has fluctuated from 0 to $0.58 \%$. The average rate has been similar compared with Poland (0.096) measured through the same period (Czarkowski et al., 2008). In Hungary, according to available data from 2000 - 2004, the incidence was slightly lower (0.084) (Svobodová et al., 2006). In the Czech Republic only imported cases of human CE were recorded in last years (Doležal et al., 2008). Decrease of CE occurrence in pig and ruminants over the last decade in the above four countries correlates with a decline of incidence in humans compared with 1990's. Ukraine is with 44.370 registered animal CE cases per year among most heavily infected countries (Šmatlová \& Papežíková, 2005). The prevalence of parasite varies substantially in different geographical zones; highest occurrence in humans in southern steppe zone of Ukraine is confined to sheep-raising areas (Malczewski et al., 2002). $32 \%$ of sheep, $20 \%$ of cattle and $9 \%$ of pigs were infected in this region in late 1980's (Shablovskaya et al., 1989).

The contribution of infections in cattle and sheep to transmission of CE appears to be marginal in Slovakia. In both ruminants only sterile cysts were mostly recorded in our observations (Turčeková et al., 2003). Over the period of $2000-2008$, the prevalence of CE in slaughtered cattle ranged from $0.002 \%(2006,2007)$ to $0.04 \%$ (in 2008), with the average annual rate $0.01 \%$. In sheep the average annual prevalence was $0.79 \%$. These values were likely partly overestimated due to occasional categorization of Taenia-type cysts as Echinococcus-type in slaughters, given that intention was to provide solely echinococcal cysts for the current survey. Larval stages of Taenia spp. (cysticercus) were presented in livers by fluid-filled cyst containing a single invaginated protoscolex. Prevalence of cysticercosis in pig in Slovakia in 2000 - 2008 ranged from 0.002 to $0.006 \%$ (Štefančíková \& Dubinský, 2000 2008). Numbers of Taenia infections in Slovakia substantially decreased after 1981 following prohibition of preparing improperly cooked meat in restaurants and further decline was registered after 1989 owing to socioeconomic changes implying marked decrease of cattle rearing (Štefančíková \& Dubinský, 1995).

Further studies on E. granulosus establishment in Slovakia will be focused on epidemiological and genetic studies combined with factors as age-prevalence, genetic variant/prevalence, age-intensity and logistic modeling that might more precisely elucidate local epidemiological factors and ecological patterns of transmission necessary to implement an effective regional control strategy.

\section{Acknowledgements}

The study was supported by the Slovak Research Grant Agency VEGA under the contract Nos. 2/7186/27, 2/0134/09) and the Slovak and Research Developmental Agency under the contract No. APVV-51-027605).

\section{References}

Altintas, N., Orenay, S., Reyhan, E., Turk, M., Asci, M., Turel, S., Yolasigmaz, A. Altintas, N. (2007): Genotoxic effects of albendazole in patients medicated for cystic echinococcosis. Helminthologia, 44: 57 - 61

Bart, J. M., Morariu, S., Knapp, J., Ilie, M. S., Pitulescu, M., Anghel, A., Cosoroaba, I., Pairroux, R. (2006): Genetic typing of Echinococcus granulosus in Romania. Parasitol. Res., 98: 130 - 137

BruŽInskaité, R., Šarkūnas, M., TORgerson, P. R., Mathis, A., DePlazes, P. (2009): Echinococcosis in pigs and intestinal infection with Echinococcus spp. in dogs in southwestern Lithuania. Vet. Parasitol., 160: 237 - 241

BuDKE, C. M. (2006): Global socioeconomic impact of cystic echinococcosis. Emerg. Inf. Dis., 12: 296 - 303

Capuano, F., Rinaldi, L., Maurelli, M. P., Perugini, A. G., Veneziano, V., Garippa, G., Genchi, C., Musella, V., CRIngOli, G. (2006): Cystic echinococcosis in water buffaloes: epidemiological survey and molecular evidence of ovine (G1) and buffalo (G3) strains. Vet. Parasitol., 137: $262-268$

Cruz-Reyes, A., Constantine, C. C., Boxell, A. C., HobBs, R. P., Thompson, R. C. A. (2007): Echinococcus granulosus from Mexican pigs is the same strain as that in Polish pigs. J. Helminthol., 81: $287-292$

Ćulafić, D. J, Katić-Radivojević, S., Kerkez, M., VukČEvić, M., RANKOVIĆ, V. STEFANOVIĆ, D. (2007): Liver cystic echinococcosis in humans - a study of 30 cases. Helminthologia, 44: $157-161$

Czarkowski, P., Cielebąk, E., Dacka, P., Kondej, B. (2008): Infectious diseases and poisonings in Poland in 2007. In Bulletin of the National Institute of Hygiene, Warsaw, Poland, $165 \mathrm{pp}$.

Daniel Mwambete, K., Ponce-Gordo, F., Cuesta- 
BANDERA, C. (2004): Genetic identification and host range of the Spanish strains of Echinococcus granulosus. Acta Trop., 91: $87-93$

Dinkel, A., Tackmann, K., Schulze, C., Drewes, T., Romig, T., MAckenstedT, U. (2006): First record of the pig strain (G7) of Echinococcus granulosus in Germany. In Deutsche Gesellschaft für Parasitologie, 22. Jahrestagung, Wien, 22. - 25. 2. 2006, p. 139

Doležal, B., Ryska, M., Jurenka, B., NÁplava, P., VlachovskÁ, E., Kalas, L., Hrabal, P. (2008): Diagnosis and tretament of Echinococus liver cysts in role 2. Voj. zdr. listy, 77: $80-84$

Dueger, E. L., Gilman, R. H. (2001): Prevalence, intensity, and fertility of ovine cystic echinococcosis in the central Peruvian Andes. Trans. R. Soc. Trop. Med. Hyg., 95: $379-383$

Eckert, J., ThOmpson, R. C. A., Lymbery, A. J., Pawlowski, Z. S., Gottstein, B., Morgan, U. M. (1993): Further evidence for the occurrence of a distinct strain of Echinococcus granulosus in European pigs. Parasitol. Res., 79: $42-48$

Gevorgyan, H., Dinkel, A., Mackenstedt, U., Romig, T. (2006): Cystic echinococcosis in Armenia: host species and Echinococcus genotypes. In Deutsche Gesellschaft für Parasitologie, 22. Jahrestagung, Wien, 22. - 25. 2. 2006, p. 147

Gonzalez, L. M., Daniel-Mwambete, K., Montero, E., Rosenzvit, M. C., McManus, D. P., GÁrate, T., Cuesta-BANDERA, C. (2002): Further molecular discrimination of Spanish strains of Echinococcus granulosus. Exp. Parasitol., 102: 46 - 56

Guarnera, E. A., Parra, A., Kamenetzky, L., Garcia, G., Gutierrez, A. (2004): Cystic echinococcosis in Argentina: evolution of metacestode and clinical expression in various Echinococcus granulosus strains. Acta Trop., 92: 153 - 159

Kamenetzky, L., Canova, S. G., Guarnera, E. A., RosenZVIT, M. C. (2000): Echinococcus granulosus: DNA extraction from germinal layers allows strain determination in fertile and nonfertile hydatid cysts allows strain determination in fertile and nonfertile hydatid cysts. Exp. Parasitol., 95: 122 - 127

Kamenetzky, L., Gutierrez, A. M., Canova, S. G., RosenzVIT, M. C. (2002): Several strains of Echinococcus granulosus infect livestock and humans in Argentina. Infect. Genet. Evol., 2: 129 - 136

KęDrA, A. H., Swiderski, Z., TKACh, V. V., DubinskÝ, P., PAWlowski, Z., STEFANiaK, J., PAWlowski, J. (1999): Genetic analysis of Echinococcus granulosus from humans and pigs in Poland, Slovakia and Ukraine. A multicenter study. Acta Parasitol., 44: 248 - 254

Kędra, A. H., TKACH, V. V., Swiderski, Z. P., PAWlowski, Z., EMETS, A., PAWlowski, J. (2000): Molecular characterisation of Echinococcus granulosus from a wild boar. Acta Parasitol., 45: 121 - 122

Kinčeková, J., PAVlinová, J., DubinskÝ, P. JR., Bober, J., Vrzgula, A., ZaChar, M. (2008): Occurrence of echinococcosis and its clinical symptoms in humans - current status in Slovakia. Slov. Vet. J., 33: $170-172$

LAVIKAInen, A., Lehtinen, M. J., LAAKSONEN, S., ÅGRen, E., OKSANEN, A., MERI, S. (2006): Molecular characterization of Echinococcus isolates of cervid origin from Finland and Sweden. Parasitology, 133: 565 - 570

MALCZEWSKI, A. (2002): CE and AE in Eastern Europe. In: Craig, P., PAwlowski, Z. (Eds): Cestode Zoonoses: Echinococcosis and Cysticercosis: An Emergent and Global Problem. IOS, Amsterdam, The Netherlands, pp. $81-89$

McManus, D. P., Zhang, L., Li, J., BARTley, P. B. (2003): Echinococcosis. Lancet, 632: 1295 - 1304

Moks, E., Jõgisalu, I., Valdmann, H., SAArma, U. (2008): First report of Echinococcus granulosus G8 in Eurasia and a reappraisal of the phylogenetic relationships of 'genotypes' G5-G10. Parasitology, 135: 647 - 654

NaKaO, M., McManus, D. P., Schantz, P. M., Craig, P. S., ITO, A. (2007): A molecular phylogeny of the genus Echinococcus inferred from complete mitochondrial genomes. Parasitology, 134: 1 - 10

PAWLOWSKI, Z. S. (1985): Epidemiological basis for chemotherapy of human echinococcosis. Int. J. Clin. Pharmacol. Res., 5: 75 - 78

PAWLOWSKI, Z. S. (1997): Critical points in the clinical management of cystic echinococcosis: a revised review. In: Andersen, F. L., Ouhelli, H., KaChani, M. (Eds): Compendium on Cystic Echinococcosis. Brigham Young University PrintServices, Provo, Utah, USA, pp. 199 - 235 RAUSCH, R. L. (1993): The Biology of Echinococcus granulosus. In: Andersen, F. L., ChAI, J. J., LiU, F. J. (Eds): Compendium on Cystic Echinococcosis with Special Reference to the Xinjiang Uygur Autonomous Region, the People's Republic of China. Brigham Young University PrintServices, Provo, Utah, USA, pp. $27-56$

Rinaldi, L., Maurelli, M., Veneziano, V., Capuano, F., Perugini, A. G., Cringoli, S. (2008): The role of cattle in the epidemiology of Echinococcus granulosus in an endemic area of southern Italy. Parasitol. Res. 103: 175 - 179 Rogan, M. T., Hai, W. Y., Richardson, R., ZeYhle, E., CRAIG, P. S. (2006): Hydatid cysts: does every picture tell a story? Trends Parasitol., 22: 431 - 438

Romig, T., Dinkel, A., Mackenstedt, U. (2006) The present situation of echinococcosis in Europe. Parasitol. Int., S187 - S191

Rosenzvit, M. C., Zhang, L. H., KamenetzKy, L., Canova, S. G., Guarnera, E. A., McManus, D. P. (1999): Genetic variation and epidemiology of Echinococcus granulosus in Argentina. Parasitology 118: 523 - 530

SAARMA, U., JÕGISAlU, I., MOKS, E., VARCASIA, A., Lavikainen, A., Oksanen, A., Simsek, S., Andresiuk, V., Denegri, G., González, L. M., Ferrer, E., GÁrate, T., Rinaldi, L., MARAVILla, P. (2009): A novel phylogeny for the genus Echinococcus, based on nuclear data, challenges relationships based on mitochondrial evidence. Parasitology, 136: $317-328$

Scott, J. C., Stefaniak, J., PaWlowski, Z. S., MCMANUS, D. P. (1997): Molecular genetics analysis of human cystic hydatid cases from Poland: identification of a 
new genotypic group (G9) of Echinococcus granulosus. Parasitology, 114: 37 - 43

Shablovskaya, E. A., Bulgakov, V. A., Ponomareva, V. E., DANKo, O. P., VoloshchuK, S. D., KiKot, V. I. (1989): Hydatidosis in the Ukrainian SSR. Med. Parazitol. Parazitarn. Bol., 6: 49 - 51

ŠMATlovÁ, K., PAPEŽíKOVÁ, I. (2005): Cystic hydatidosis. Vet. Lékař, 3: 129 - 133

ŠnÁBEL, V., D’AMElio, S., MATHiOPOUlos, K., TURČEKOVÁ, L', DUBINSKÝ, P. (2000): Molecular evidence of the presence of a G7 genotype in Slovakia. J. Helminthol., 74: $177-181$

Šnábel, V., NakaO, M., Ševcová, D., Huettner, M., Romig, T., SzÉnÁsi, Z., CieleckA, D., GeOrgescu, S. O., SAlamatin, R., Emets, A., Ito, A., KuzminA, T., DUBINSKÝ, P. (2008): Survey of genetic polymorphism in Echinococcus granulosus in central-eastern Europe, with detection of the two G7 lines and three G1 variants. In Abstracts from the 10th European Multicolloquium of Parasitology (EMOP 10), August 24 - 28, 2008. Paris, France: European Federation of Parasitology, 2008, pp. $159-160$

ŠnáBel, V., Altintas, N., D’Amelio, S., NaKaO, M., Romig, T., Yolasigmaz, A., Gunes, K., Turk, M., Busi, M., Hüttner, M., ŠEvcová, D., Ito, A., Altintas A., DUBINSKÝ P. (2009): Cystic echinococcosis in Turkey: genetic variability and first record of the pig strain (G7) in the country. Parasitol. Res., 105: 145 - 154

ŠTeFAnČíkOVÁ, A., DubinskÝ, P. (1995): Status and prognosis of the incidence of helminthic zoonoses in Slovakia. Helminthologia, 32: 247 - 250

ŠTEFANČÍKOVÁ, A., DUBINSKÝ, P. (2000 - 2008): Surveillance of zoonoses. Helminthozonoses of the Slovak Republic. State Veterinary and Food Administration of the Slovak Republic and Parasitological Institute SAS, Bratislava, Slovakia
Svobodová, V., Dubinský, P., Cabaj, W., Sréter, T., KolÁR̆OVÁ, L., MosKWA, B., MALCZEWSKI, A., STEFANIAK, J. (2006): Risk for diseases acquired from food and in nature. In International Visegrad Fund - Noviko, Brno, Czech Republic, 91 pp.

ThOMPson, R. C. A. (2008): The taxonomy, phylogeny and transmission of Echinococcus. Exp. Parasitol., 119: $439-446$

TKACH, V. V., SWIDERSKI, Z., DrOZDZ, J., DEMIASZKIEWICZ, A. W. (2002): Molecular identification of Echinococcus granulosus from wild European beaver, Castor fiber (L.) from North-Eastern Poland. Acta Parasitol., 47: 173 - 176

TurČekovÁ, L., ŠnÁBel, V., D’Amelio, S., Busi, M., DUBINSKÝ, P. (2003): Morphological and genetic characterization of Echinococcus granulosus in the Slovak Republic. Acta Trop., 85: 223 - 229

Varcasia, A., Canu, S., Lightowlers, M. W., Scala, A., GARIPPA, G. (2006): Molecular characterization of Echinococcus granulosus strains in Sardinia. Parasitol. Res., 98: 273 - 277

Varcasia, A., Canu, S., Kogkos, A., Pipia, A. P., Scala, A., GARIPPA, G., SeImenis, A. (2008): Molecular characterization of Echinococcus granulosus in sheep and goats of Peloponnesus, Greece. Parasitol. Res., 102: 815 818

Webster, G. A., CAmeron, T. W. M. (1961): Observations on experimental infections with Echinococcus in rodents, Can. J. Zool., 39: $877-891$

Yang, Y. R., McManus, D.P., Huang, Y., Heath, D.D. (2009): Echinococcus granulosus infection and options for control of cystic echinococcosis in Tibetan communities of western Sichuan Province, China. Negl. Trop. Dis., 3: e426 